\title{
Electric Energy Saving of Air-Conditioner for High-Rise Buildings
}

\author{
yunos Ngadiman, ahmad Nur Aizat Ahmad, norhadilah Abdul Hamid, abdul TALIB Bon
}

\begin{abstract}
The application of energy resources has stimulated a dramatic increased especially in developing countries. Consequently, the energy-saving factor of local and non-domestic residents such as the industry, service centers and others has been a concern especially on electronic device equipment such as environmental warming, local ventilation and air conditioning equipment. The method of reducing the use of air conditioners is divided into two methods practiced by engineers is called an active and passive way that alters the model of air conditioning and green building materials. Therefore, this research is intended to reduce the air conditioner energy consumption by avoiding the unnecessary space cooling and stabilize the cooling air at usage area in the high-rise building such as big and tall ceiling hall. Experiment with prototype is chosen to use as the methodology to testing and evaluate the concept according to the change of temperature. Thus, the expected outcomes of experiment are the difference of temperature between upper and lower level will be more significant and lower part is cooler than upper part as the cooling air is avoiding to flowing up by air preventer. Besides that, the air preventer which replace with car tinted able to reflect heat will reduce the heat transfer to the lower part or usage area to reduce the internal heat addition in the high-rise constructing that also benefits to decrease the energy depletion. However, the limitation of air preventer is transmittance of light, costly if apply high quality and bigger space area, and thin layer that may easily broke. The suggested materials that may take in consideration to replace the tinted using Thermoplastic Elastomer (TPE) rubber.
\end{abstract}

Keywords: Air conditioner, Space characteristic, Cooling capacity, Temperature changes

\section{INTRODUCTION}

From 1984 to 2004, the world energy consumption carbon dioxide emissions had increased $49 \%$ and $43 \%$, repectively. has resulted in anxiety associated with excess supply, lack of energy sources and also the effects of global warming. The report also states [12]. According to reports from the Intergovernmental Panel on Climate Change (IPCC), global warming will increase by $4.0^{\circ} \mathrm{C}$ from $34.8 \%$ to $38.9 \%$ used for heating, ventilation and air-conditioning (HVAC) [23] based on the total energy requirements (PER) in the United States.

The per capita energy intensity in Malaysia in 2008 [6] has shown its usage of $1,652 \mathrm{kWh}$ and will continue to increase in neither in developed nor developing countries.

Revised Manuscript Received on September 14, 2019.

yunos Ngadiman, Faculty of Technology Management and Business, Universiti Tun Hussein Onn Malaysia, 86400 Parit Raja Johor, Malaysia. (Email: yunos@uthm.edu.my)

ahmad Nur Aizat Ahmad,Faculty of Technology Management and Business, Universiti Tun Hussein Onn Malaysia, 86400 Parit Raja Johor, Malaysia.

norhadilah Abdul Hamid, Faculty of Technology Management and Business, Universiti Tun Hussein Onn Malaysia, 86400 Parit Raja Johor, Malaysia.

abdul TALIB Bon, Faculty of Technology Management and Business, Universiti Tun Hussein Onn Malaysia, 86400 Parit Raja Johor, Malaysia.
The energy demand for thermal comfort in urban and rural area and between day and night season also different due to the changes of weather and temperature [22]. On a clear summer afternoon, the air temperature in a typical city is as much as $2.58^{\circ} \mathrm{C}$ higher than in the surrounding rural areas and urban electric demand rises by $2-4 \%$ for each $1^{\circ} \mathrm{C}$ rise in daily maximum temperature above a threshold of 15 to 20 ${ }^{\circ} \mathrm{C}$ [1]. The rate of increase in energy consumption in the yearly air conditioning system has shown an increase of 226 $\mathrm{kWh} / \mathrm{m}^{2}$ in office buildings in Northern Europe. The previous study showed that the annual energy consupmtion at office buildings located in Northern Europe which equipped with air conditional system was increased to 226 $\mathrm{kWh} / \mathrm{m}^{2}[18]$.

\section{METHODOLOGY}

In addition, the traditional cooling steam compression system (VCS) used by the power fossil fuel through the emission of carbon dioxide (CO2) produced to the atmosphere [5]. Furthermore, there are addressing that larger space area needed more higher horsepower of air conditioner or more energy as larger space consists of more heat [4]. Reducing air energy consumption is very important to reduce carbon dioxide emissions [8]. The objective of this study is to assess the use of air conditioning in the lecture halls of UTHM based on the physical dimension of space area and recommend a new ideal system that may put effort for future study to reduce the overall use of air energy [9]. The recommendation of new ideal system may benefit for increase the efficiency of air conditioner, stabilize the cooling air at the usage area of building and reduce the air conditioner energy consumption [19] by avoiding the unnecessary space-cooling area as shown in Figure 1 and 2.

The Figure 1 shown an example of single level of building wich 400 square feet and 4 horsepower of air conditioner is needed. Figure 2 shown a tall ceiling building and divided into three level which bottom as usage area where occupancy being to. However, top and middle level as non-usage. Usually central air conditioner is apply for tall building and cooling air pass through the non-usage area to the usage area. For this, 12 horsepower of air conditioner is needed to cooling the whole building from top to the bottom. By this is considered as unnecessary space cooling as pass through of non usage area. The air preventer that shown in Figure 3 has avoiding the cooling air flowing up to the non-usage area and stabilize the cooling air. The hot air also been avoid to influence the temperature at bottom level. By this, the temperature with air preventer may like be various between these three level.

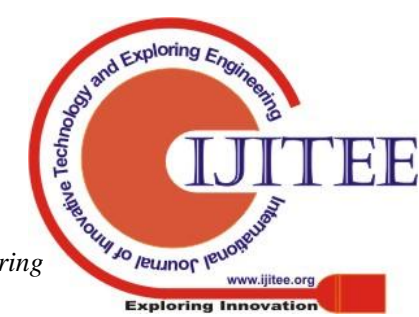




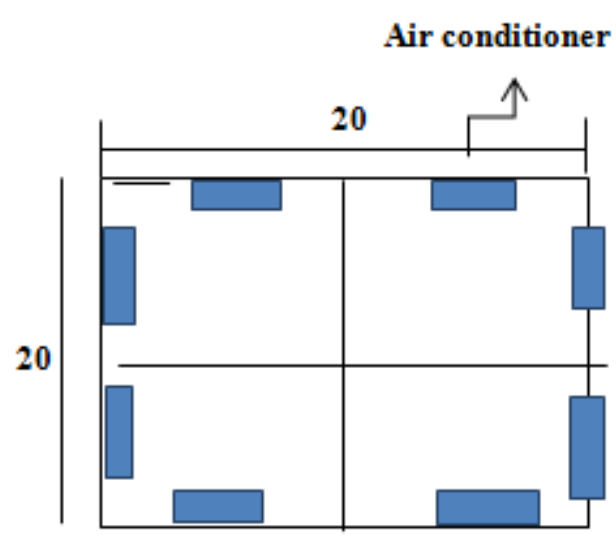

Figure 1: Single flow of air conditioner

Referring to Figure 1 is the installation of 8 units of one floor air conditioning with the following formula:

$$
\begin{aligned}
& 20 \times 20 \mathrm{ft}^{2}: \\
& =400 \mathrm{ft}^{2} \\
& =(2 \times 2) \text { horsepower } \\
& =4 \text { horsepower }
\end{aligned}
$$

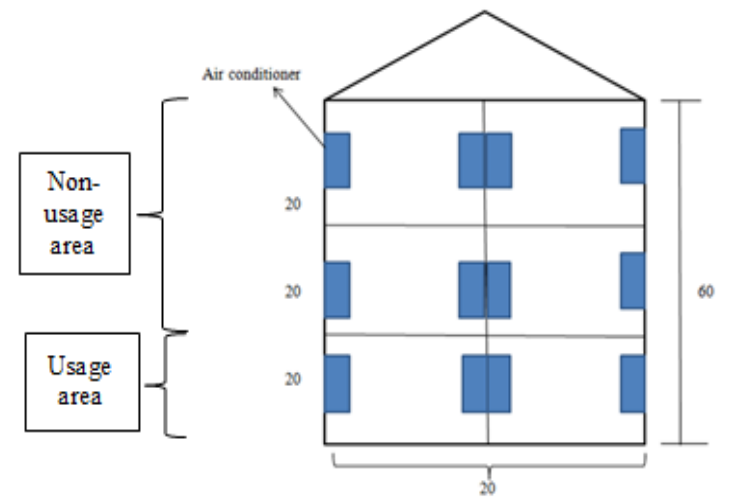

Figure 2: 12 Horsepower energies required for the entire building
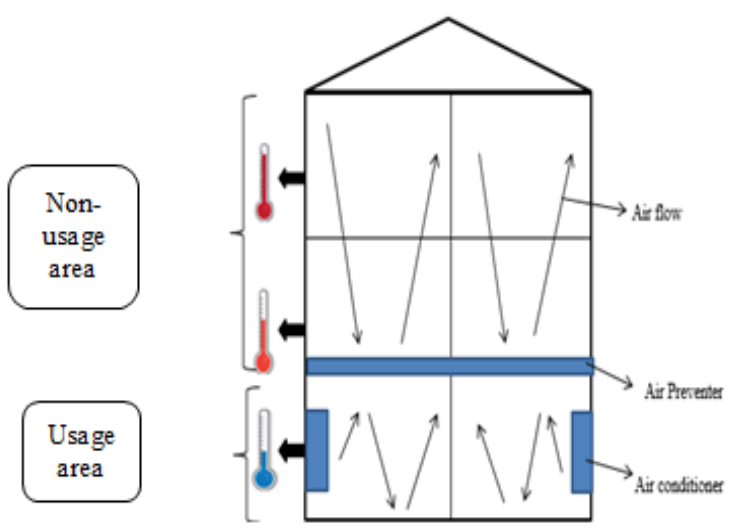

Figure 3: Air preventer in building

\section{AIR CONDITIONER\& RESULTS}

The definition of 'Air conditioning' is a process of temperature regulation, humidity as well as air purity in the interior that is capable of controlling the cooling of capacity. The role of air conditioning is to maintain the comfort of a conducive life market. Basically, various types of airconditioning equipment are in the market namely airconditioning and centralized air-conditioning. In addition, the load of the air conditioner is divided into reasonable and burdened loads. These two free types are maintained in depth so they can be balanced with their needs. The traditional cooling steam compressor (VCS) or system absorption steam (VSS) is a process of cooling the air inside the hall by condensing the water vaporization process. The ventilation process is dehumidify and reheated to meet the temperature requirements for eliminating the required latent heat and interior. Therefore, the energy required for the ventilation process from the supply temperature to the low vapor evaporation temperature (below the dew point air). When the reasonable heat ratio (SHR) has condensed the space is low, then the sum of these two components will show a boasting increase [5].

Air conditioning capacity is set by peak load requirements and control types with conditions to be maintained during peak and partial loads. Thus, it is difficult to measure and estimate peak and partial loads (McGraw-Hill, 1965). In order to reduce the power consumption of air conditioners it is required to take into consideration in perspective or different factors that will affect the energy cooling load such as building construction, external and internal load [11].

\subsection{Factors Affecting Energy Consumption}

\subsubsection{Coordination of Sunray and Building Location}

The coordination of the sunray is refer to the location which space will be with respect to compass point which affected by the nearby permanent structure of shading, reflective surfaces like sand, water, or parking lot, as well as sun and wind effect. For instance, if the conditioned room is oriented to the sun rays entering windows, consequently the solar heat gain to room temperature and space will be higher, and higher energy consumption is needed to cool down the space and maintained the inner condition of room. Nevertheless, shading devices is able to reduce the solar heat gain as well as reduce the energy consumption. Other than that, the energy consumption of air conditioner will be higher if the building is located nearby to parking lot, seasides, or urban sides with the tall buildings. In other words, if the building located nearby the water sources with higher moisture density level of the atmosphere ozone and lower daily temperature will reduce the energy consumption of air conditioner. On the other hand, the building located in urban canyons which employed natural ventilation has been found a reduction in wind speed inside the canyon and air flow reduction up to 10 times during the day that corresponds to undisturbed ambient wind conditions [21].

\subsubsection{Construction Materials}

It is well known that, the rise of solar heat into space is significantly affect by building materials. Thermal insulation is important in order to reduce energy consumption in buildings by increase heat loss ability through the construction materials of building envelope which has lower thermal conductivity or absorption of heat [14]. In the modern urban environment there is a darker nature and become warmer, leading to the creation of a "hot island" city

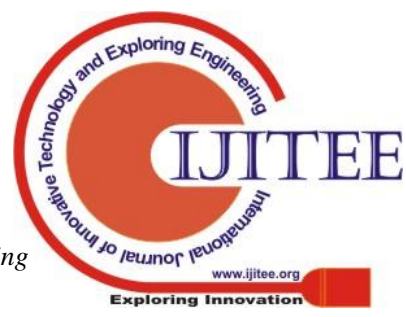


[1]. For example, building materials needed for a building that is in cold weather like Mongolia will be at $-30^{\circ} \mathrm{C}$. The storage of latent heat materials in Phase Change Materials (PCM) is a concern due to elevation levels of storage with low temperature waves. It can trap direct solar energy sources or heat energy through natural convection [17]. In addition, Life Cycle Assessment (LCA) has also been established to enhance economic, social and environmental sustainability to fulfill the consumer needs, especially to produce eco-friendly products, improve productivity and market competitiveness in green construction.

Additionally, from the construction of building materials, the estimates of the solar roof and U-value roof have resulted in increased refinement of the solar roof to reduce the load-saving from 18-93\% [22]. For example, a green roof will also have a positive effect on the interior of the building because it has been found that good for sun radiation.

\subsubsection{Volume Sizes of Spaces}

Dimensions of physical dimensions of long, wide, and elevated altitude factors and logical thinking that large physical spaces will require more energy use to adjust the temperature levels of all areas. For example, if the 1.5-tonne air-conditioner is incorporated into a 120-square foot room, the amount of electricity required varies per hour compared to a 150-square feet room. This is due to the heat that consists in that area are more as it absorbs solar heat gain on bigger sphere area of building such as a room of 150 square feet, hence extra electricity is needed to cooling down the chamber.

In another sense, one physical dimension will also be based on the shape of the building. From previous studies it also states that the design of the building will affect the consumption of air-conditioning during the day and the movement of air due to turbulence in solar radiation affecting air circulation, heat increase, loss of capacity or insulation system [25]. A study was conducted to study energy consumption in homes with different dimensions of physical dimensions [26] and found that the height of a building is significantly influenced the system's insulation factor [15].

\subsubsection{The Internal loads}

An internal load means the heat generated in the supplied space depends on the lighting factors, the computing device, the machining and the other. This will result in increased temperature according to prolonged space [20]. In previous studies conducted in measuring the energy for cooling and heating of office interior space also noted that internal loads including building users, lighting levels and equipment were higher at $75 \%$ compared to the total annual cooling load of the building. The occupancy pattern can be including both heat release from electrical appliance and people [10]. The densely populated area will release the self-immolation of the body's internal metabolism into space and the humaninspired system of carbon dioxide emission. With this, with more and more people in the vast area will need more air energy. Thus, long-term energy savings can be achieved by scheduling better energy emissions during phase operation and determining the maximum level of dwelling for certain horsepower to prevent defective air [27]. In ensuring the source of error and increasing forecasts, an energy model for indoor use to various input parameters has to be re-identified and evaluated [2]

\subsubsection{Air conditioner}

There are several type of air conditioner such as room air conditioner and central air conditioner. Additionally, it has been specially designed to reduce air energy with five energy efficiency assessments on air conditioners [13] which indicated as energy saving and cost saving air conditioner [6]. By this, the model of air conditioner that chosen for applying in particular space area must be taken in consideration.

Besides that, suitable size of horsepower air conditioner that applied in the rooms is important as concern about the wasted energy that may overcooling or overheating.The suitable sizes of air conditioner horsepower for applying in rooms have to align with the volume sizes and the acceptable occupancy level. The horsepower refer to the power that used to transfer the heat from inner building and cooling the space to unnecessary space-cooling area.

\subsection{Efficiency of air conditioner}

COP is a performance assessment value for efficient measurement of cooling systems operating at a single outdoor temperature. Whereas, the EER is to set energy efficiency to measure the cooling capacity of the given energy [7]. Higher COP and EER positions mean higher efficiency and explain less energy usage [11]. The higher the cost of air conditioning with the EER will promise more budget than one lower EER system, the higher the EER will also cool around and more economical. The formula shown as follows:

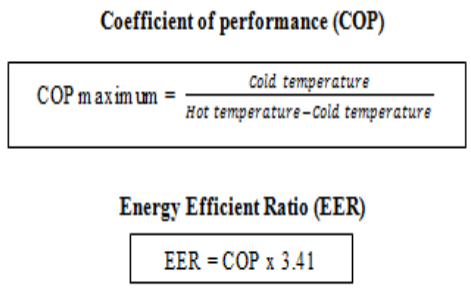

Ergy Efficient Ratio (EER)

\section{RECOMMENDATION}

The new idea system which called as Air Preventer is purposely apply for tall ceiling building or high-rise building such as mosque. The central air conditioner usually apply for tall ceiling building which the cooling air flowing down from the top to the bottom of usage area as shown in the Figure 2. This consider of unnecessary space cooling and waste of energy. For this, the air preventer as shown in Figure 3 is functioning to avoid the heat gain from the roof top and electrical appliances such as lighting flow down to the usage area that needs more energy power for space cooling. Besides that,the air preventer able to avoid the cooling air flowing up to non-usage area as well. For this, split package air conditioner is consider more suitable rather than central air conditioner. The materials of air preventer 
can be consider of using thermoplastic elastomer rubber (TPE)which is good for thermal resistance that could avoiding heat and it able to made in clear transparent that will not affect inner beauty of hall. The air preventer is flexible that is adjustable to open-closed and moving up and down depends on the demand of thermal comfort.

This new system can be have further details testing and study in the future.

\section{CONCLUSION}

The research was conducted to study the relationship between the volume sizes of space area and air conditioner energy consumption. Based on the results has proved that the volumes space area will effect to the indoor temperature by comparing to the final indoor temperature of lecture hall 6 and 8 that larger space area has higher indoor temperature. By using this concept, the researcher apply it to the high-rise building which consider waste of energy as unnecessary space cooling and recommend a new idea system that called as Air Preventer with TPE rubber materials to avoid the heat and cooling air flow to the unwanted area in order to reduce the air conditioner energy consumption and increase the efficiency as well [8].

\section{REFERENCES}

1. Akbari, H., Pomerantz, M., \& Taha, H. (2001). COOL SURFACES AND SHADE TREES TO REDUCE ENERGY USE AND IMPROVE AIR QUALITY IN URBAN AREAS, 70(3), 295-310.

2. Chow, T. T., Lin, Z., \& Wang, Q. W. (2000). Effect of building re-entrant shape on performance of air-cooled condensin\&g units, 143-152.

3. Chua, K. J., \& Chou, S. K. (2010). Energy performance of residential buildings in Singapore. Energy, 35(2), 667678. http://doi.org/10.1016/j.energy.2009.10.039

4. Conditioner, B. C. A., Package, C. S., \& Model, F. B. (n.d.-a). ENERGY STAR ® Program Requirements Product Specification for Air Source Heat Pump and Central Air Conditioner Equipment Eligibility Criteria, $1-5$.

5. Daou, K., Wang, R. Z., \& Xia, Z. Z. (2006). Desiccant cooling air conditioning: a review, 10, 55-77. http://doi.org/10.1016/j.rser.2004.09.010

6. Energy, A., \& Group, W. (2011). PEER REVIEW ON ENERGY EFFICIENCY, (May).

7. Fischer, C., \& Fischer, C. (2016). “ Feedback on Household Electricity Consumption: A Tool for Saving Energy?" a tool for saving energy?, (April). http://doi.org/10.1007/s12053-008-9009-7

8. Garrison, N., Horowitz, C., Lunghino, C. A., Devine, J, \& Beckman, D. S. (2012). Can Reduce Energy Use , Address Climate Change, and Protect Water Resources in Southern California Looking Up: How Green Roofs and Cool Roofs, (june).

9. Gul, M. S., \& Patidar, S. (2015). Understanding the energy consumption and occupancy of a multi-purpose academic building. Energy \& Buildings, 87, 155165.http://doi.org/10.1016/j.enbuild.2014.11.027

10. Hart, M., \& Dear, R. De. (2004). Weather sensitivity in household appliance energy end-use, 36 (October 2003), 161-174. http://doi.org/10.1016/j.enbuild.2003.10.009

11. Kikegawa, Y., \& Genchi, Y. (2006). APPLIED Impacts of city-block-scale countermeasures against urban heatisland phenomena upon a building $\tilde{\mathrm{O}} \mathrm{s}$ energyconsumption for air-conditioning, 83, 649-668. http://doi.org/10.1016/j.apenergy.2005.06.001
12. Kwok, A. G., \& Rajkovich, N. B. (2010). Addressing climate change in comfort standards. Building and Environment, 45(1), 18-22. http://doi.org/10.1016/j.buildenv.2009.02.005

13. Lam, J. C., Wan, K. K. W., Tsang, C. L., \& Yang, L. (2008). Building energy efficiency in different climates, 49 2354-2366. http://doi.org/10.1016/j.enconman.2008.01.013

14. Materials, B., Castells, F., \& Rovira, U. (2009). Sustainability in the construction industry: a review of recent developments based on LCA . Construction Build Mater Sustainability in the construction industry: A review of recent developments based on LCA, (April 2016). http://doi.org/10.1016/j.conbuildmat.2007.11.012

15. Mirrahimi, S., Farid, M., \& Chin, L. (2016). The effect of building envelope on the thermal comfort and energy saving for high-rise buildings in hot - humid climate, 53, 1508-1519. http://doi.org/10.1016/j.rser.2015.09.055

16. Niachou, A., Papakonstantinou, K., Santamouris, M., Tsangrassoulis, A., \& Mihalakakou, G. (2001). Analysis of the green roof thermal properties and investigation of its energy performance, 33, 719-729.

17. Pasupathy, A., Velraj, R., \& Seeniraj, R. V. (2008). Phase change material-based building architecture for thermal management in residential and commercial establishments, 12, 39-64. http://doi.org/10.1016/j.rser.2006.05.010

18. Perez-Lombard, Jose Ortiz \& Christine Pout (2008). A review of energy consumption, 40(3), 394-398. Sadineni, S. B., Madala, S., \& Boehm, R. F. (2011). Passive building energy savings: A review of building envelope components. Renewable and Sustainable Energy Reviews, 15(8), 3617-3631. http://doi.org/10.1016/j.rser.2011.07.014

19. Saidur, R., Masjuki, H. H., \& Jamaluddin, M. Y. (2007). An application of energy and exergy analysis in residential sector of Malaysia, 35, 1050-1063 http://doi.org/10.1016/j.enpol.2006.02.006

20. Santamouris, M., Papanikolaou, N., Livada, I., Koronakis, I., Georgakis, C., Argiriou, A., \& Assimakopoulos, D. N. (2001). ON THE IMPACT OF URBAN CLIMATE ON THE ENERGY CONSUMPTION OF BUILDINGS, 70(3), 201-216

21. Synnefa, A., Santamouris, M., \& Akbari, H. (2007) Estimating the effect of using cool coatings on energy loads and thermal comfort in residential buildings in various climatic conditions, 39, 1167-1174. http://doi.org/10.1016/j.enbuild.2007.01.004

22. Termodina, D. De, Vale, U. De, Vale, U. De, Termodina, D. De, \& Vale, U. De. (2001). Daily Air Temperature and Electricity Load in Spain, 1413-1421.

23. Wan, K. K. W., Li, D. H. W., Liu, D., \& Lam, J. C. (2011). Future trends of building heating and cooling loads and energy consumption in different climates. Building and Environment, 46(1), 223-234 http://doi.org/10.1016/j.buildenv.2010.07.016

24. We, I., \& Last, C. (n.d.). Heat Transfer: Conduction Convection, and Radiation.

25. Yu, Z., Fung, B. C. M., Haghighat, F., \& Yoshino, H. (n.d.). A Systematic Procedure to Study the Influence of Occupant Behavior on Building Energy Consumption.

26. Zhou, N., Fridley, D., Mcneil, M., Zheng, N., 


\section{AUTHORS PROFILE}

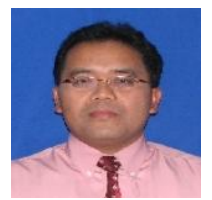

Yunos Ngadiman is working as lecturer at Faculty of Technology Management and Business, Universiti Tun Hussein Onn Malaysia. Her major research interest is Technology Commercialisation. His main area of interest is Industrial and Manufacturing Engineering.

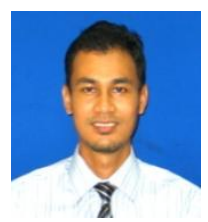

Ahmad Nur Aizat Ahmad currently works at the Department of Production and Operations, Universiti Tun Hussein Onn Malaysia. His research interest includes Manufacturing Engineering and Industrial Engineering.

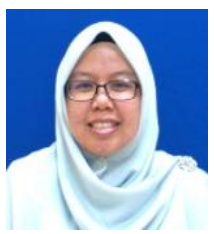

Norhadilah Abdul Hamid is working as lecturer at Faculty of Technology Management and Business, Universiti Tun Hussein Onn Malaysia. Her major research interest is Technology Commercialisation.

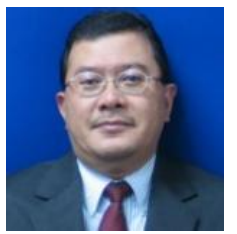

Abdul Hadi Nawawi, $\mathrm{PhD}$ is a Professor of Technology Management at Faculty of Technology Management and Business, Universiti Tun Hussein Onn Malaysia. Currently, he is the director of teaching factory at Universiti Tun Hussein Onn Malaysia. His main area of interests are Operation Research and Management Science. 